\title{
Induction and Inhibition of Intestinal P-glycoprotein and Effects on Etoposide Absorption
}

\author{
Bee-Lien LEU, *Ming-Derg LAI, Jin-ding HUANG \\ Departments of Pharmacology and *Biochemistry \\ National Cheng Kung University, Medical College \\ Tainan 70101, Taiwan, Republic of China
}

\begin{abstract}
[OBJECTIVES] P-Glycoprotein actively extrudes a number of anti-cancer drugs, such as etoposide, from cancer cells. Its expression in cancer cells after a period of drug exposure was known as a common mechanism of multi-drug resistance (mdr). At normal physiologic condition, P-glycoprotein also expresses in various organs, such as lung, kidney, liver, adrenal tissues, pancreas, colon, as well as in the brush border membrane of the small intestine.
\end{abstract}

Etoposide tablet is clinically used as an anti-cancer drug for oral therapy. P-Glycoprotein located at the brush border membrane may pump out orally absorbed etoposide therefore decrease its bioavailability. We hypothesized that induction of intestinal P-glycoprotein might increase the etoposide efflux from blood into the intestinal lumen and, therefore, decrease the etoposide absorption. Similarly, inhibition of intestinal P-glycoprotein might increase the etoposide absorption. The effect of intestinal P-glycoprotein level inflection on the absorption of anticancer drugs is of great interest and clinical importance. In this study, we reported that etoposide absorption in the everted gut sacs can be modulated by induction and inhibition of P-glycoprotein in the small intestine. We have also studied the effect of a mdr-reversing agent, quinidine, on the absorption and exsorption of etoposide in the whole animal.

[METHODS] Male Sprague-Dawley rats bred and housed in the animal center of National Cheng Kung University, Medical College, were used. Rats were intraperitoneally injected with $10 \mu \mathrm{g} / \mathrm{kg}$ of sodium arsenite, $0.5 \mathrm{mg} / \mathrm{kg}$ of sodium butyrate, or $170 \mu \mathrm{g} / \mathrm{kg}$ of 3methylcholanthrene (3-MC) daily for 5 days. The inducing effect were monitored by measuring efflux of the rhodamine 123 and confirmed by Western blotting and reverse transcription/polymerase chain reaction (RT/PCR). Etoposide was assayed with an HPLC method modified from a previous report ${ }^{1}$. Rhodamine 123 was measured with a fluorescence spectrophotometer (excitation wavelength: $350 \mathrm{~nm}$, emission wavelength $560 \mathrm{~nm}$ ).

Four segments of the rat intestine of approximately $25 \mathrm{~cm}$ were taken and everted sacs were prepared as originally developed by Wilson \& Wiseman ${ }^{2}$. The sacs were filled with $3 \mathrm{~mL}$ of Tyrode solution and placed in a $50-\mathrm{mL}$ Tyrode solution containing $100 \mu \mathrm{g} / \mathrm{mL}$ of etoposide. Two hundred $\mu \mathrm{L}$ of solution inside the sacs was taken every $10 \mathrm{~min}$. For inhibition studies, 1 $\mathrm{mg} / \mathrm{mL}$ of quinidine, a P-glycoprotein inhibitor, or $0.1 \mathrm{U} / \mathrm{mL}$ of C219 (Centocor Diagnostics, Inc., Malvern, PA, USA), a monoclonal antibody of P-glycoprotein, or $0.2 \mathrm{~N}$ of 5'adenylylimidodiphosphate (AMPPNP), a non-hydrolyzable ATP analog, was pretreated for 30 min before adding etoposide.

Brush-border membrane vesicles (BBMV) were prepared from jejunum and ileum as desbribed in the literature ${ }^{3}$. The protein content of BBMV was determined by using Bio-Rad protein assay kit. BBMV containing equal amount of protein was loaded and electrophoresed on SDS-PAGE, was then transferred onto nitrocellulose filter paper, and probed with $0.075 \mu \mathrm{g} / \mathrm{mL}$ of C219 monoclonal antibody. Visualization of protein bands was performed with enhanced 
chemiluminescence (ECL) detection kit using horseradish peroxidase labelled secondary antibody as suggested by the manufacturer (Amersham International Plc, Buckinghamshire, UK).

RNA of the intestinal tissues was extracted as Chromazynski and Sacchi's method ${ }^{4}$. The sequence of primers for aldolase was GGCAAGGGCATCCTGGCTGCAGA (141-163) and TAACGGGCCAGAACATTGGCATT (583-561). The sequence of primers for $m d r 1 b$ gene was GAGGTGAAGAAGGGCCAGACG (3175-3195) and TTCTGGATGGTGGACAGGCGGTGA (3822-3799) $)^{5}$. In RT/PCR reaction, the RNA was preheated at $70{ }^{\circ} \mathrm{C}$ for $10 \mathrm{~min}$ and chilled in ice. For cDNA synthesis, 200 units of MMLV reverse transcriptase (BRL, Gaithersburg, MD) was added to a $30 \mu \mathrm{L}$ reaction volume containing RNA, 40 units RNase inhibitor (Promega, Masison, WI), $10 \mathrm{mM}$ dithiothreitol, $333 \mu \mathrm{M} 4 \mathrm{dNTPs}, 20 \mathrm{mM}$ Tris $\mathrm{HCl}$ (pH 8.3), $50 \mathrm{mM} \mathrm{KCl}$, $2.5 \mathrm{mM} \mathrm{MgCl}_{2}, 100 \mu \mathrm{g} / \mathrm{mL} \mathrm{BSA}$, and $100 \mathrm{pmol}$ of two forward primers for aldolase and $m d r 1 b$ gene. The reaction mix was incubated at room temperature for $10 \mathrm{~min}$, then at $37^{\circ} \mathrm{C}$ for $30 \mathrm{~min}$, and stopped by heating at $95^{\circ} \mathrm{C}$ for $5 \mathrm{~min}$. The PCR reaction was performed by adding the RT reaction product to the mixture containing $100 \mathrm{pmol}$ of reverse primers for aldolase and $m d r l b$ gene, $6 \mu \mathrm{L}$ of $5 \mathrm{mM} \mathrm{MgCl}_{2}, 2 \mu \mathrm{L}$ of $5 \mathrm{mM}$ dNTP, $7 \mu \mathrm{L}$ of $10 \mathrm{x}$ Taq buffer $(500 \mathrm{mM} \mathrm{KCl}, 100$ $\mathrm{mM}$ Tris $\mathrm{HCl}, \mathrm{pH} 9.0$, and $15 \mathrm{mM} \mathrm{MgCl}_{2}$ ), $55 \mu \mathrm{L} \mathrm{H}_{2} \mathrm{O}$, and 3.5 units of Taq polymerase. PCR was performed with 40 cycles of $45 \mathrm{sec}$ at $95^{\circ} \mathrm{C}, 2 \mathrm{~min}$ at $55^{\circ} \mathrm{C}$, and $2 \mathrm{~min}$ at $72{ }^{\circ} \mathrm{C}$. The reaction product were analyzed on $2 \%$ agarose gel with ethidium bromide staining.

An in situ single-pass perfusion technique was used for exsorption studies ${ }^{6}$. A similar recirculated perfusion technique was used for absorption studies. The jugular vein was cannulated with silastic tubing and used for drug infusion. Blood samples was collected via the carotid artery cannula. Intestinal perfusate was perfused at approximately $20 \mathrm{~mL} / \mathrm{hr}$ and collected hourly. The intestinal clearance of etoposide was calculated by dividing the rate of excretion by the mean drug concentration in serum during the sample period.

[RESULTS \& DISCUSSION] Etoposide was transported from the mucosal side (bulk solution) to the serosal side (inside sac) after a lag period of approximately $10 \mathrm{~min}$ at different segments of the small intestine. When P-glycoprotein inhibitors were added, the etoposide efflux decreased and therefore etoposide concentration in the sacs was increased. The inhibition of etoposide efflux by $\mathrm{C} 219$ consisted of a P-glycoprotein-specific and a non-specific components. The negative antibody of $\mathrm{C} 219$ revealed non-specific inhibition of etoposide efflux. When the non-hydrolyzable ATP analog, AMPPNP, or quinidine was used, etoposide absorption in both ileum and jejunum was increased. Pretreating rats with sodium arsenite, sodium butyrate, or 3MC for 5 days, on the other hand, increased the intestinal P-glycoprotein and decreased the rate of etoposide absorption in both jejunum and ileum. In RT/PCR, mRNA of rat mdrlb gene was increased in the jejunum, whereas the change was insignificant in the ileum. The inducing agents increased the exsorption of rhodamine 123 in the ileum, but not in the jejunum.

When quinidine was infused simultaneously, the rate of etoposide absorption increased, as reflected in higher etoposide concentration in serum. The increase was dependent on the rate of quinidine absorption. In exsorption studies, the intestinal clearance of etoposide was decreased from $41.7 \pm 7.2 \mathrm{~mL} / \mathrm{hr} / \mathrm{kg}$ to $18.4 \pm 3.8 \mathrm{~mL} / \mathrm{hr} / \mathrm{kg}$ when quinidine was infused at $1 \mathrm{mg} / \mathrm{hr}(\mathrm{P}<0.05)$. The total clearance of etoposide was also decreased from $276 \pm 28 \mathrm{~mL} / \mathrm{hr} / \mathrm{kg}$ to $170 \pm 16 \mathrm{~mL} / \mathrm{hr} / \mathrm{kg}$ by quinidine co-administration $(\mathrm{P}<0.05)$. 
The in vitro data support the hypothesis that etoposide is exsorbed by P-glycoprotein after its absorption. When P-glycoprotein was inhibited by the substrate inhibitor (quinidine), the unhydrolyzable ATP analog (AMPPNP), or the monoclonal antibody of P-glycoprotein (C219), etoposide exsorption was decreased and absorption can be substantially increased. On the other hand, when the intestinal P-glycoprotein was induced, etoposide exsorption increased and absorption decreased. The in situ studies further support our hypothesis. Increased etoposide absorption and decreased etoposide exsorption were observed when the P-glycoprotein inhibitor, quinidine, was co-administered.

Sodium arsenite, sodium butyrate, and 3-MC increased $m d r l b$ mRNA in the jejunum, but not in the ileum. These inducing agents, on the other hand, increased P-glycoprotein in both the jejunum and ileum. It appeared that the induced P-glycoprotein in the ileum (ileum-type) was not from $m d r l b$ gene. Interestingly, rhodamine 123 efflux was also increased in the jejunum, but not in the ileum. The results suggest that rhodamine 123 was transported by the P-glycoprotein encoded by $m d r l b$ gene, but not by the ileum-type P-glycoprotein. Because etoposide absorption was decreased in both ileum and jejunum, we might conclude that the ileum-type P-glycoprotein transports etoposide. We, however, do not have data to suggest if there is ileum-type Pglycoprotein present in the jejunum, and whether rat $m d r l b$ encoded P-glycoprotein can transport etoposide or not.

An increased serum concentration of etoposide may be due to an increased absorption, or a decreased elimination. Quinidine decreased the total clearance of etoposide. In the exsorption study, quinidine increased the serum concentration of etoposide by $32 \%$. When the same rate of quinidine was infused in the absorption study, the etoposide concentration in serum increased more than 2 folds. It is clear that quinidine not only decreased the rate of etoposide elimination, but also increased the rate of etoposide absorption.

In this study, we have demonstrated that quinidine may increase etoposide absorption as well as inhibit etoposide elimination at a concentration below its therapeutic range. Quinidine may also potentiate etoposide action by inhibiting multidrug resistance of cancer cells. Further study is needed to ensure the clinical benefit of the combination of these two drugs.

[ABSTRACT] P-Glycoprotein (Pgp) actively pumps a number of antineoplastic drugs, such as etoposide, out of cancer cells and causes multidrug resistance. Pgp also expresses at the brush border membrane of the small intestine under the normal physiologic condition. We hypothesized that induction or inhibition of intestinal Pgp might increase or decrease the etoposide efflux from blood into the intestinal lumen and, therefore, decrease or increase the absorption of etoposide, respectively. Etoposide absorption was studied using an everted gut sac preparation of rat jejunum and ileum. In this study, we found that treating rats with sodium arsenite $(10 \mu \mathrm{g} / \mathrm{kg})$, sodium butyrate $(0.5 \mathrm{mg} / \mathrm{kg})$, or 3-methylcholanthrene (3-MC, $170 \mu \mathrm{g} / \mathrm{kg}$ ) for 5 days decreased the intestinal absorption of etoposide in both jejunum and ileum. Western blotting with C219, a monoclonal antibody of Pgp, confirmed the increase of the intestinal Pgp in both ileum and jejunum. With reversed-transcription/polymerase chain reaction of rat $m d r l b$ gene, we found that arsenite and butyrate induction increased $m d r l b$ mRNA in the jejunum, whereas the inducing effect of arsenite, butyrate, or 3-MC in the ileum was not significant. Addition of C219 at 0.1 $\mathrm{U} / \mathrm{ml}$ or 5'-adenylylimidodiphosphate at $0.2 \mathrm{~N}$, a non-hydrolyzable ATP analog, increased the absorption of etoposide. Quinidine, an antiarrythmics, has been demonstrated to circumvent the multidrug resistance in cell lines, possibly by interfering with Pgp function. Adding quinidine at 1 
$\mathrm{mg} / \mathrm{ml}$ to the everted gut sac preparation also substantially increased the absorption of etoposide. In situ absorption of etoposide was also studied by intraluminal perfusion of the drug in anesthetized rats. Intravenous infusion of quinidine at either 1 or $2 \mathrm{mg} / \mathrm{hr}$ both increased serum level of etoposide. Such an increase was shown to be dose-dependent. Intravenous infusion of etoposide at $0.2 \mathrm{mg} / \mathrm{hr}$ resulted in luminal exsorption of the drug in small intestine. The intestinal clearance rate of etoposide was $41.7 \pm 7.2 \mathrm{ml} / \mathrm{hr} / \mathrm{kg}$. When etoposide was administered at the same infusion rate with $1 \mathrm{mg} / \mathrm{hr}$ of quinidine, the intestinal clearance of etoposide decreased to $18.4 \pm 3.9 \mathrm{ml} / \mathrm{hr} / \mathrm{kg}$. These in situ data confirmed that the intestinal Pgp mediated the efflux of etoposide and the use of Pgp-inhibiting agent such as quinidine may increase the intestinal absorption of etoposide. In addition to etoposide, the efflux of rhodamine 123, which is a common substrate used to measure Pgp function, in the everted gut sacs was also studied. Despite of the Pgp level increase in both ileum and jejunun shown in Western blotting, rhodamine 123 efflux increased only in the jejunum, but not in the ileum. The results suggest that there are multiple members of Pgp family in the rat small intestine. Rhodamine 123 was probably transported by a Pgp encoded by $m d r l b$, and etoposide was transported by another Pgp member.

\section{[REFERENCES]}

1. Chow, D., Shah, J. (1987) J. Chromatogr. 396: 217-223

2. Wilson, T. H., Wiseman, G. (1954) J. Physiol. (Lond) 120: 63-72

3. Sheikh, M. I., Moller, J. V. (1987) Preparation and use of renal and intestinal plasma membrane vesicles for toxicological studies. In: Snell, K., Mullock, B. (eds) Biochemical Toxicology: a Practical Approach. IRL press, Oxford, pp 153-182

4. Chromazynski, P., Sacchi, N. (1987) Anal. Biochem. 162: 156-159

5. Silverman, J. A., Raunio, H., Gant, T. W., Thorgeirsson, S. S. (1991) Gene 106: 229-236

6. Huang, J. D. (1990) 42: 167-170 